\title{
Impact of Solvent on the Characteristics of Standardized Binahong Leaf (Anredera cordifolia (Ten.) Steenis)
}

\author{
Dwitiyanti ${ }^{1}$, Yahdiana Harahap ${ }^{2}$, Berna Elya ${ }^{3}$, Anton Bahtiar ${ }^{4, *}$
}

Dwitiyanti ${ }^{1}$, Yahdiana Harahap ${ }^{2}$, Berna Elya ${ }^{3}$, Anton Bahtiar ${ }^{4, *}$

'Graduated Program of Faculty of Pharmacy, Universitas Indonesia, Kampus UI Depok, West Java 16424, INDONESIA.

${ }^{2}$ Department of Bioanalysis and

Bioequivalence, Faculty of Pharmacy,

Universitas Indonesia, Kampus UI Depok West Java 16424, INDONESIA.

${ }^{3}$ Department of Phytochemistry, Faculty of

Pharmacy, Universitas Indonesia, Kampus UI

Depok, West Java 16424, INDONESIA.

${ }^{4}$ Department of Pharmacology and

Toxicology, Faculty of Pharmacy, Universitas

Indonesia, Kampus UI Depok, West Java

16424, INDONESIA.

\section{Correspondence}

\section{Anton Bahtiar}

Department of Pharmacology and

Toxicology, Faculty of Pharmacy,

Universitas Indonesia, Kampus UI Depok,

West Java 16424, INDONESIA.

E-mail: anton.bahtiar@farmasi.ui.ac.id

History

- Submission Date: 11-09-2019;

- Review completed: 25-09-2019;

- Accepted Date: 09-10-2019.

\section{DOI : 10.5530/pj.2019.11.226}

Article Available online

http://www.phcogj.com/v11/i6s

\section{Copyright}

(c) 2019 Phcogj.Com. This is an openaccess article distributed under the term of the Creative Commons Attribution 4.0 International license.

\section{ABSTRACT}

Background: Binahong is a plant that has the potential to be used as a traditional herbal medicine in Indonesia, and has several kinds of classes of compounds, one of them is a flavonoids glycosides (vitexin). Previous research reported that binahong leaves have pharmacological activities as antihyperglycemic, antihyperlipidemic, antibacterial, and others. A traditional plant that has proven efficacious needs to be standardized to ensure the quality and its safety. Objective: This study aimed to characteristics of binahong leaves simplicia obtained from Bogor, West Java. Materials and Methods: The crude extract was obtained by the maceration method using $40 \%, 70 \%$, and $96 \%$ ethanol solvent. The selected extract then standardized, which includes macroscopic and microscopic observations and sets the standard parameter values binahong leaf extract. Parameters LCMS to identify active compounds semiquantitatively. Results: The yield of binahong ethanol extract from $40 \%, 70 \%, 96 \%$ showed a value of $10.9 \%, 11.4 \%$, and $12.32 \%$, respectively. From these results, $96 \%$ ethanol extract has proceeded for standardization. Macroscopic observation results showed that binahong leaves simplicia has a fine and notched form with 5-10 cm long and 3-7 cm diameter. The microscopic binahong leaves contain palisade tissue, parenchymal tissue, chlorophyll grains, rosette Caoxalate crystals, and spiral type. Phytochemical screening of binahong leaves showed the presence of alkaloids, flavonoids, saponins, tannins, steroids, and phenolic compounds. The standardization of binahong leaves ethanol extract down showed a levels of ethanol-soluble extract $>14.8 \%$, water-soluble extract content $>13.5 \%$, drying $<10 \%$, water content $<8.9 \%$, total ash content $<7.2 \%$. LCMS profiles showed that ethanolic extract $40 \%, 70 \%$, and $96 \%$ all contained vitexin at retention time 5.02 minutes, and $\mathrm{m} / \mathrm{z}$ values 433.1111 . Conclusion: $96 \%$ ethanolic extract of binahong leaves contains vitexin with pharmacognostic parameters carried out following the standards listed in the Indonesian herb pharmacopeia.

Key words: Anredera cordifolia, Standardization, Simplicia, Extract, LCMS.

\section{INTRODUCTION}

Diabetes mellitus is a disease caused by various causes. Diabetes mellitus is caused by insulin resistance, insulin deficiency, and abnormal insulin secretion. Diabetes mellitus is characterized by high levels of glucose in the blood (hyperglycemia) and the detection of fat, and protein. ${ }^{1}$ International Diabetes Federation (IDF) data for 2017 stated that diabetes mellitus (DM) sufferers in the world are estimated to continue to increase by $48 \%$ from 425 million sufferers in 2017 to increase by around 629 million in 2045, while in Asia according to IDF showed an increase of $84 \%$ from 82 million sufferers in 2017 increased to 151 million in 2045. Indonesia ranks 6th out of 10 countries with the most significant diabetes in the world, with 10 million sufferers. ${ }^{2}$

Therapy in the treatment of diabetes is to use oral antidiabetic drugs that can be done with one type of drug or combination. One of the drugs that are widely used for diabetes is sulfonylureas. One of the drugs used by people with type 2 diabetes is Glibenclamide from sulfonylurea group. Glibenclamide is one of the most well-known antidiabetic drugs and belongs to the sulfonylurea group which works to reduce oxygen levels by using pancreatic Langerhans beta cells to produce insulin. ${ }^{3}$ Besides, drugs derived from natural ingredients can be a therapeutic choice by patients with diabetes mellitus. The use of natural materials as an adjuvant to DM treatment has long been carried out by the people of Indonesia. One of the natural ingredients that have the potential and was used to reduce blood sugar levels is the Binahong plant

Binahong pharmacological activities included antihyperlipidemia, anti-inflammatory, analgesic, and antipyretic. ${ }^{4}$ Other studies reported that binahong leaf extract could inhibit a-glucosidase with an IC50 value of $54.24 \mu \mathrm{g} / \mathrm{mL} .{ }^{5}$ Binahong leaf methanol extract at a dose of $50 \mathrm{mg} / \mathrm{kg}$ body weight and 200 $\mathrm{mg} / \mathrm{kg}$ body weight could reduce the blood glucose levels of alloxan-induced mice on the 7 th day by $61.02 \%$ and $60.68 \%$ while on the 14 th day a decrease in glucose levels by $75.64 \%$ and $66.61 \%$, histologically could repair $\beta$-pancreatic cell damage. ${ }^{6}$

Binahong research, it contains several secondary metabolites of flavonoids, alkaloids, phenols, saponins, triterpenoids and sterols. ${ }^{7}$ The methanolic extract of binahong leaves contains 8 glucopyranosyl-4 ', 5,7-trihydroxyprolavones used as blood glucose-lowering agents, ${ }^{8}$ and triterpenoid saponin (boussingoside, momordin, 
and larreagenin) from Boussingaultia baselloides as hypoglycemia. ${ }^{9}$ Binahong leaf glycoside flavonoids contain vitexin (8-beta-Dglucopiranosilapigenin).$^{10}$ The current study was to find related to the characteristics and standardization of binahong plants and the effect of solvent concentration in attracting active substances vitexin.

\section{MATERIALS AND METHODS}

\section{Materials}

Vitexin (powder) as a reference standard was purchased from Sigma-Aldrich (Germany), water, methanol, and acetonitrile for chromatography (LC-MS Grade) (Merck, Germany). All other chemicals for analysis (Merck, Germany), Mayer reagent, Dragendorf reagent. Other ingredients for identification of the compound and the identification of powdered microscopic. micropipette (Socorex, Swiss), blue tip (Nesco, Indonesia), yellow tip (Nesco, Indonesia), Spectrophotometer UV-Vis (Shimadzu UV-1601, Jepang), Erlenmeyer, beaker glass (Pyrex, Indonesia), LCMS ( Waters xevo G2-XS Qtof, United States of America), Maceration containers, blenders, vacuum rotary evaporators (Eyela, Japan), Oven.

\section{Collection and authentication of plant material}

The plant material of Binahong (Anredera cordifolia (Ten.) Steenis) leaves were collected from Bogor Medicinal Plant Research Institute (BALITRO Anredera cordifolia (Ten.) Steenis leaves were identified by Indonesian Insitute of Sciences, Research Center for Biology with identification number 2285 / IPH.1.01 / If.07 / IX / 2018. The leaves were separated, washed, dried, milled into powder, and then stored in a closed container for further use.

\section{Macroscopic and microscopic evaluation}

Leaves of binahong were identified macroscopically to determine shape, margins, color, a base of the leaves. The microscopically of binahong leaves was made on the leaf powder to evaluate the fragment of the identifier. Evaluation of morphologically plants were observed based on the description given in Indonesian Herb Pharmacopoeia. ${ }^{11}$ Organoleptic of plants were characterise were observed, noted and photographs were taken in the original environment.

\section{Extraction}

The extraction was done by the maceration method using ethanol solvent. Preliminary extraction for screening was done with $20 \mathrm{~kg}$ of fresh leaves of Binahong was washed and dried aerated for 4 days. After being dried, it is powdered into $1090 \mathrm{gr}$, then sifted. The powder obtained was extracted by maceration using $40 \%, 70 \%$, and $96 \%$ ethanol, then filtered using filter paper. The extract was dried with a vacuum of a rotary evaporator at a temperature of $50^{\circ} \mathrm{C}$ and then continued to dry in water bath temperature of $50^{\circ} \mathrm{C}$.

\section{The yield of Binahong leaf ethanol extract}

The rendering of binahong leaf ethanol extract was obtained from the simplicia powder of binahong leaf extract, which was extracted by maceration method three times of replication and using ethanol solvent with various concentrations, then filtered to obtain clear extract. The ethanol extract collected was evaporated with a water bath until a thick extract was obtained

\section{Simplisia standardization of Binahong leaves}

Specific standardization parameters include identity and organoleptic simplicia, while non-specific parameters include such as determination of water content and ash content. For ash content, Binahong leaves extract were weighed as much as $2.5 \mathrm{~g}$, put into a platinum or silicate crucible, then flattened, flattened carefully until the charcoal runs out, cooled, and weighed. If, in this way the charcoal cannot be lost, hot water is added, filtered through the remaining filter paper, and filter paper flattened in the same crucible. The filtrate is put into a crucible, evaporated and flattened to a fixed weight. Ash content was calculated from extracts that had been dried in the air.

\section{Standardization of ethanol extract of Binahong leaves}

Specific standardization parameters include the identity or description of plant nomenclature, organoleptic, phytochemical screening of the contents of the extracted identity, levels of water-soluble compounds and levels of soluble compounds in ethanol. The nonspecific standardization parameters carried out in this study include determination of drying losses, water content, ash content, microbial contamination. ${ }^{12}$

\section{Phytochemical screening}

The identification of content compound in the extract was carried out on the most active extract (ethanol). The extracts were subjected to preliminary phytochemical investigation for the detection of following compounds; flavonoids, alkaloids, tannins, steroid, and saponins. The procedures described by Indonesian Herb Pharmacopoeia and Harborne. $^{13}$

\section{Water and ethanol soluble extract}

Five gram of powder that has been dried in the air. Enter into the clogged pumpkin, add $100 \mathrm{~mL}$ of saturated chloroform water, repeatedly shake for the first 6 hours, leave for 18 hours. Strain, evaporate $20 \mathrm{~mL}$ of the filtrate to dry in a shallow flat-bottomed dish that has been heated 1050 and tapped, heat the remainder at 1050 until the weight remains. Calculate the level in\% water-soluble essence, otherwise qualifies if it is not less than $13.5 \%$. Calculate the level in\% ethanol-soluble extract, otherwise eligible if not less than $19.6 \%$.

\section{Preparation of LCMS instruments}

The column used in this study is Phenomenex C18 (50mm x $20 \mathrm{~mm}$ ), the pump used is a non-fixed flow mode or gradient elution to obtain the optimum mobile phase composition during analysis. Automatic phase composition with a gradient of $10 \%-30 \%$ acetonitrile solution with a time adjustment. While the column temperature is set at room temperature of $25^{\circ} \mathrm{C}$. First the instrument was prepared by purging the LC column in order to remove the remaining eluents remaining in the column, after purging, then proceed with pumping of the eluent or the mobile phase for approximately 5 minutes and equilibrate for 5 minutes.

\section{RESULTS AND DISCUSSION}

\section{Plant determination}

Anredera cordifolia (Ten.) Steenis or better known as Binahong, according to the Indonesian Herbal Pharmacopoeia Literature Supplement 2, comes from the Basselaceae tribe and is supported by the results of determination No. 2285 / IPH.1.01 / If.07/ IX / 2018 at the Herbarium Bogoriense Institute of Biology Research Center LIPI Cibinong, West Java. The results obtained are these plants come from the Basselaceae tribe. ${ }^{12}$

\section{Microscopic and macroscopic}

Macroscopic testing is carried out by observing the physical and organoleptic shape of the binahong leaf. According to the Ministry of Health of the Republic of Indonesia (2011), Leaf is green, cordatus shape, pointed, and leaf base notched. Leaf size long 7,5-9,5 cm and diameter, $5,1-7,0 \mathrm{~cm}$ in width. ${ }^{11}$ Simpicia identifies that have been made on the binahong leaf Leaflets are triangular or ovoid or heartshaped. Repeated pinnate leaves, yellowish-brown leaf bones, both 
surfaces slightly rough, rather thick, the base of the leaves are curved, curved edges, tapered edges, brownish-green color, slightly pungent odor, a slight taste and a little bitter. ${ }^{12}$

Based on the Ministry of Health of the Republic of Indonesia (2011) organoleptic binahong The form of coarse powder, brown color, aromatic smell. ${ }^{11}$

Microscopic observations were carried out by transverse, and longitudinal slices of binahong leaves and observations were made of the constituent tissue, vessel beam type, leaf type, stomata type, and existing crystals. Microscopic testing aims to determine the identification of fragments in the form of cells or tissue contained in the binahong leaf. The results obtained in binahong leaf powder found calcium oxalate crystals in rosette form, spiral shape. In the binahong leaf powder with a magnification of $10 \times 40$.

\section{Binahong leaf powder extraction}

Binahong leaf extract was obtained $10 \mathrm{~kg}$ of fresh binahong leaf, then washed and dried by aerated, and $1.41 \mathrm{~kg}$ of dry binahong leaves were obtained. Simplisia drying is done to prevent microbial growth in plants. ${ }^{13}$ After drying, binahong leaves are sorted dry and pollinated. Pollination aims to reduce particle size thereby increasing surface contact between the sample and the extraction solvent. ${ }^{14}$

The dried binahong leaves are then pulverized to obtain $1.3 \mathrm{~kg}$ of dry powder and sifted with mesh no. 40 so that $1.09 \mathrm{~kg}$ of powder is obtained. The dry powder is then macerated with $96 \%$ ethanol solvent so that the macerate is concentrated by using a vacuum rotary evaporator. The results of the concentrated extract obtained were put in an oven at 40 ${ }^{\circ} \mathrm{C}$. The extraction results can be seen in Tables 1 and 2 .

The extraction process aims to attract the chemical components contained in simplicia. In this study Binahong leaf ethanol extract was obtained from the simplicia powder of binahong was extracted by maceration method three times of replication and using ethanol solvent with various concentrations, then filtered to obtain clear macerate. The maceration method is a simple cold extraction method by immersing simplicia powder with a liquid solution. This method was chosen because the process is easy and straightforward. The ethanol macerate collected was evaporated with a water bath until a thick extract was obtained. The results obtained were then calculated, and the yield of $40 \%, 70 \%$, and $96 \%$ binahong leaves ethanol extract were showed in Table 2. Extraction screening was carried out to determine the right ethanol solvent based on spectrophotometry measurement of total flavonoid levels, calculation of extract yield results and identification of vitexin flavonoid content through LCM. 96\% ethanol solvent capable of attracting higher flavonoids compared with $40 \%$ and $70 \%$ ethanol solvents. The extraction method used is maceration using $96 \%$ ethanol solvent. Ethanol is a suitable solvent for extraction, in addition to ethanol also can search with a full polarity. Ethanol more easily penetrates cellular membranes so that it can extract intracellular material from the plants used. ${ }^{15}$ Besides, ethanol can inhibit the growth of fungi and most bacteria. Maceration is the process of extracting simplicia by using solvents with several shaking.

\section{Simplisia standardization of Binahong leaves}

The purpose of standardization is to ensure the quality of medicinal ingredients, which will then be used as drug preparations. The standardization process includes specific and non-specific parameters. Specific standardization parameters include checking identity and organoleptic simplicia, while non-specific parameters include such as determination of ash content.

The non-specific standardization parameters carried out in this study include determining the ash content of binahong leaf simplicia based on the ash content conducted on the ethanol extract of binahong leaves obtained in the range of $3.09 \%-4.09 \%$. In ash content testing, binahong leaves meet the ash content requirements specified in the 2011 Indonesian Herbal Pharmacopeia Supplement II edition. Ash content is said to be eligible if $<16.3 \%$. Determination of ash content is carried out to provide an overview of the mineral content that comes from plants naturally and contaminants during the harvesting process until a good and quality extract is obtained. At this stage the simplicia and extract are heated until the organic compounds, and their derivatives are destructed and evaporate until only the mineral and inorganic elements remain.

\section{Standardization of ethanol extract of Binahong leaves}

Specific standardization parameters include the identity or description of plant nomenclature, organoleptic, phytochemical screening of the contents of the extracted identity, levels of water-soluble compounds and levels of soluble compounds in ethanol. The organoleptic extract was shown in Table 3. Based on the experiment of water-soluble and

Table 1: Results of $96 \%$ ethanol extract of Binahong leaves.

\begin{tabular}{ccc}
\hline No & Result & Type \\
\hline 1 & Fresh Binahong leaves & $10 \mathrm{~kg}$ \\
2 & Dry Binahong leaves & $1,41 \mathrm{~kg}$ \\
3 & Binahong leaf powder & $1.09 \mathrm{~kg}$ \\
4 & Ethanol extract (liquid) & 8,2 liter \\
5 & Ethanol extract (thick) & $134.3 \mathrm{~g}$ \\
\hline
\end{tabular}

Table 2: Simplisia yield extracts of simplisia leaves of Binahong.

\begin{tabular}{cccc}
\hline No. & Extract Name & Colour & Yield extract (\%) \\
\hline 1. & $40 \%$ ethanol extract & Black & $10,90 \%$ \\
2. & $70 \%$ ethanol extract & Black & $11,40 \%$ \\
3. & $96 \%$ ethanol extract & Black & $12,32 \%$ \\
\hline
\end{tabular}
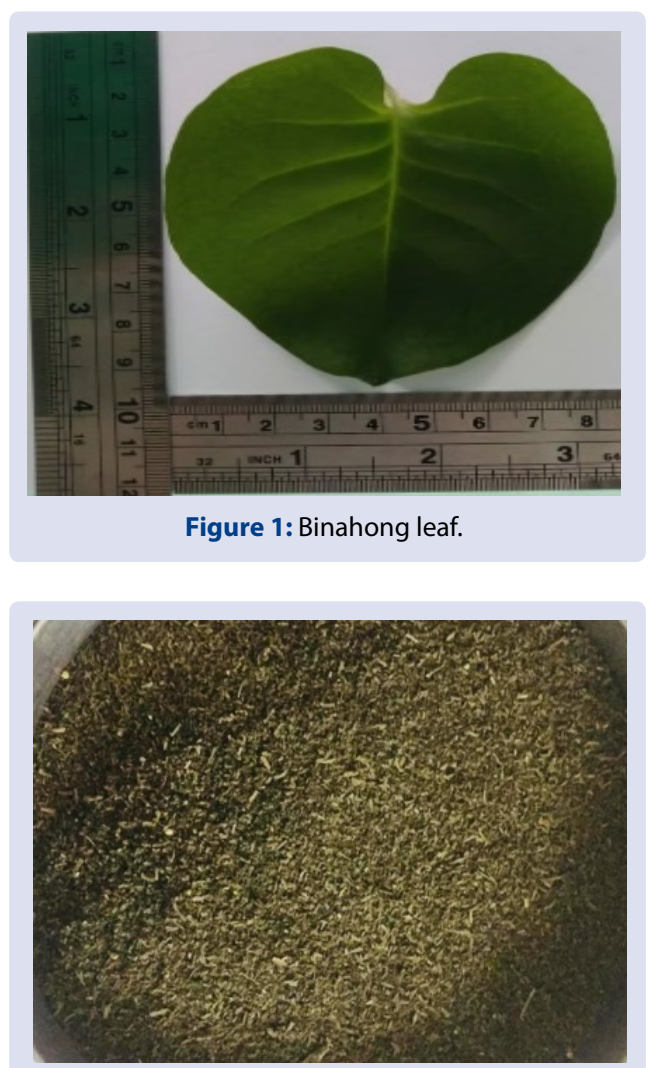

Figure 2: Binahong leaf powder. 


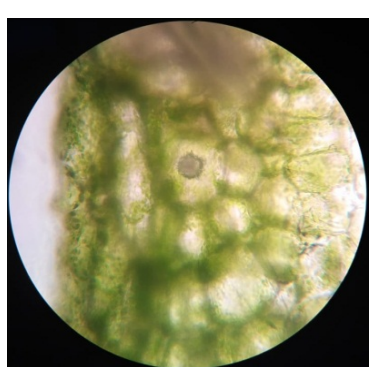

(a)

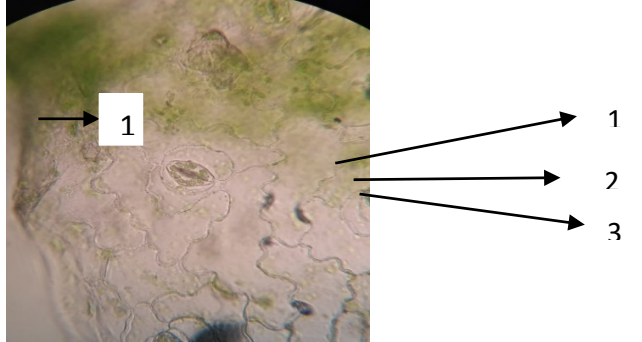

(b)

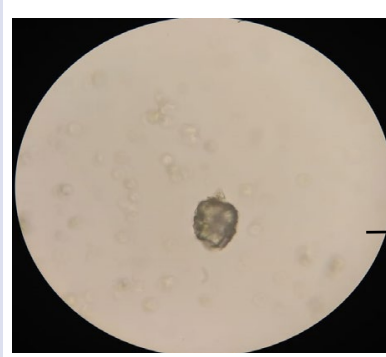

(c)

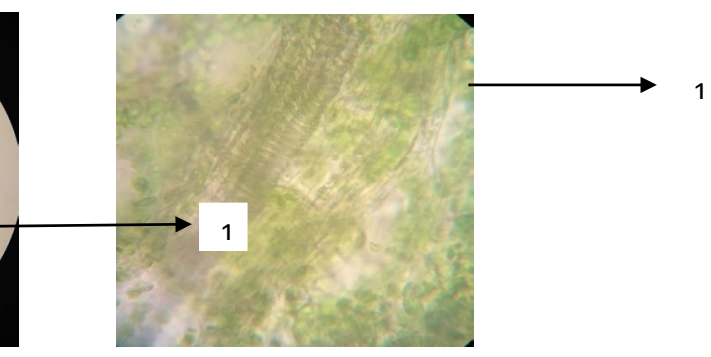

(d)

Figure 3: (a) 1. Epidermis, (b) 1. Stomata, 2. Chlorophyll, 3. Cell closing, (c) 1. Ca-Oxalate crystal in rosette, (d) 1. Thickening of the carrier beam spiral shape.

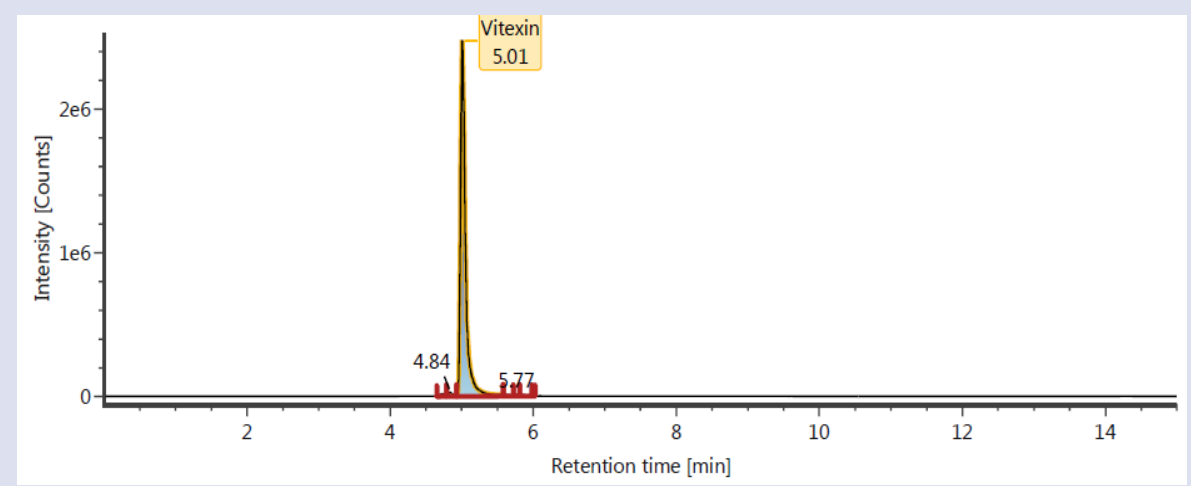

Figure 4: LCMS results of Vitexin.

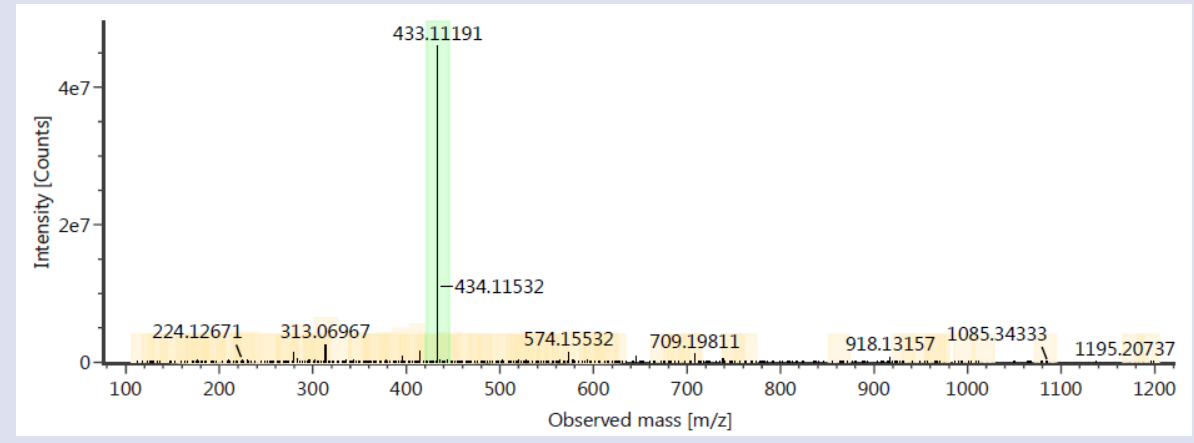

Figure 5: Vitexin ion mass spectrum fragmentation. 
ethanol soluble compounds carried out on the ethanol extract of binahong leaves were shown in Table 4.

The non-specific standardization parameters carried out in this study include the determination of drying losses, water content, ash content, and microbial contamination from ethanol extracts of binahong leaves. Based on the drying shrinkage experiments conducted on the ethanol extract, binahong leaves obtained levels in the range of $4.39 \%-6.01 \%$. Dry shrinkage aims to provide a maximum limit on the amount of compound lost in the drying process.

Water content using the Aufhaseur method, and showed 6.25\%. Water content to be eligible if $<10 \%$. The determination of water content aims to determine the amount of water content in the material after the drying process. Examination of Ash content using Gravimetry method. From the examination results obtained $0.92 \%$. The results are known that binahong leaf extract meets the ash content requirements set in Pharmacopoeia Herbal Indonesia Supplement II edition 1 of 2011.

For microbial contamination on PCA (Plate Count Agar) medium, there are 2 colonies in dilutions $10^{-4}$ and $10^{-5}$, and there are no colonies in $10^{-6}$ dilutions. PCA is used as a medium for aerobic microbes with inoculation on the surface. This PCA media is good for total microbial growth. In this research used PDA (Potato Dextrose Agar) media, this medium is used to grow or identify yeasts and molds, PDAs contain an adequate amount of carbohydrate, consisting of $20 \%$ potato extract and $2 \%$ glucose so that it is suitable for mold growth and yeast The results on the PDA medium contained no contamination, meaning that simplicia does not contain mold and mold. Examination of microbial contamination is carried out to guarantee that the extract does not contain pathogenic microbes and does not contain non-pathogenic microbes exceeding the prescribed value because it is harmful to health. The examination was carried out using bacterial growth media and mold growth media.

\section{Phytochemical screening}

Phytochemical screening was observed for binahong leaf simplicia and extract in order to find out the compounds contained in the extract. Phytochemical screening performed includes alkaloids, flavonoids, saponins, tannins, steroids, and terpenoids. The results are available in Table 5. Simplisia and extracts are then tested by qualitative phytochemicals, which aim to prove the presence or absence of certain chemical compounds in plants to be associated with their biological activity. In this study, the results of phytochemicals contained in binahong leaf extract in the form of alkaloids, flavonoids, saponins, tannins, triterpenoids/steroids and phenols. Binahong contains several secondary metabolites of flavonoid, alkaloid, phenol, saponin, triterpenoid, and sterol types. ${ }^{7}$ Alkaloids (bethanidine) and phenolic acids (p-coumaric acid) are found in the ethanol extract of binahong leaves.

Flavonoids from the ethyl acetate extract of binahong leaves, according to Rahmawati et al. have identified 3,5,3', 4'-tetrahydroxiflavonol. ${ }^{14}$ compounds, addition of $\mathrm{Mg}$ and $\mathrm{HCl}$ powders showed the presence of flavonoid compounds with positive results in brownish-red color. The brownish-red color formed is due to the reduction of flavonoid compounds by concentrated $\mathrm{Mg}$ and $\mathrm{HCl}$. Magnesium and hydrochloric acid react to form bubbles that produce $\mathrm{H} 2$ gas, while concentrated $\mathrm{Mg}$ and $\mathrm{HCl}$ metals in this test function to reduce the benzopiron nucleus contained in the flavonoid structure so that the color changes to red or orange. If in an extract there are flavonoid compounds that will form flavilium salts when adding red or orange $\mathrm{Mg}$ and $\mathrm{HCl}$. The flavonoids contained in the binahong leaf extract from fresh and dried samples according to Selawa research were $7.81 \% \mathrm{mg} / \mathrm{kg}$ and $11.23 \mathrm{mg} / \mathrm{kg} .{ }^{15}$

Tannins were identified using $1 \%$ gelatin reagents. Identification using gelatin shows positive results marked by the formation of white deposits. The presence of sediment shows the ability of tannins to precipitate the proteins contained in gelatin. Identification of terpenoids using Liebermann-Bouchard reagents (anhydrous acetic acid- $\mathrm{H}_{2} \mathrm{SO}_{4}$ ) showed positive results marked by the formation of red. The formation of these colors because of the ability of terpenoid compounds to form colors by $\mathrm{H}_{2} \mathrm{SO}_{4}$ in anhydrous acetic acid solvents.

Triterpenoid saponins found in the leaves of Binahong are boussingoside, momordin, and larreagenin. ${ }^{9}$ The extract added with distilled water is shaken for 15 minutes to form foam $1 \mathrm{~cm}$ high and stable for 15 minutes showing the presence of saponin compounds. The active compound in saponins can form foam when shaken with water and produces a bitter taste that can reduce surface tension. The formation of foam is due to the presence of glycosides, which can form froth in water that is hydrolyzed into glucose. Glycoside steroid compounds are surface-active compounds and are like a soap, can be detected based on their ability to form foam and dissolve red blood cells.

Terpenoid compounds test with the addition of ether and LiebermannBurchard reagents are showed the formation of green color. The formation of a green color due to oxidation in the group of terpenoid/

Table 3: Organoleptic observations of ethanol extract of Binahong leaves.

\begin{tabular}{cc}
\hline Parameters & Result \\
\hline Shape & Coarse powder \\
Color & Chocolate \\
Smell & Aromatic \\
\hline
\end{tabular}

Table 4: Result of standardization of ethanol extract of Binahong leaves.

\begin{tabular}{ccccc}
\hline No. & Test & Result $(\%)$ & Reference $^{12}$ & Information \\
\hline 1. & Dry shrinkage & 4.39 & No more than $10 \%$ & qualified \\
2. & Water content & 6.25 & No more than $8.85 \%$ & qualified \\
2. & Total Ash Content & 0.92 & No more than $1,64 \%$ & qualified \\
3. & $\begin{array}{c}\text { Water Soluble Sari } \\
\text { Content }\end{array}$ & 23,50 & Not less than $13,5 \%$ & qualified \\
4. & $\begin{array}{c}\text { Ethanol Soluble Sari } \\
\text { Content }\end{array}$ & 19,80 & Not less than $19,6 \%$ & qualified \\
5. & $\begin{array}{c}\text { Total Plate Number } \\
\text { Microbial }\end{array}$ & $<3,0.10^{4}$ colonies/g & $\begin{array}{c}\text { No more than } 10^{4} \\
\text { colonies/g }\end{array}$ & qualified \\
6. & $\begin{array}{c}\text { Total Plate Number } \\
\text { Yeast Mold }\end{array}$ & 0 colonies/g & $\begin{array}{c}\text { No mon } 10^{3} \\
\text { colonies } / \mathrm{g}\end{array}$ & qualified \\
\hline
\end{tabular}


Table 5: Phytochemical screening results of powder and ethanol extracts of Binahong leaves.

\begin{tabular}{|c|c|c|c|c|c|c|}
\hline $\begin{array}{c}\text { Types of } \\
\text { Secondary } \\
\text { Metabolites }\end{array}$ & Test Method & Result & $\begin{array}{l}\text { Kemuning leaf } \\
\text { Powder }\end{array}$ & $\begin{array}{c}40 \% \text { of Ethanol } \\
\text { Extracts }\end{array}$ & $\begin{array}{c}7 \% \text { of Ethanol } \\
\text { Extracts }\end{array}$ & $\begin{array}{c}96 \% \text { of Ethanol } \\
\text { Extracts }\end{array}$ \\
\hline \multirow[t]{3}{*}{ Alkaloid } & $\begin{array}{c}\text { Bouchardat } \\
\text { reagent }\end{array}$ & $\begin{array}{l}\text { Chocolate } \\
\text { Deposition }\end{array}$ & + & + & + & + \\
\hline & Mayer reagent & Yellow precipitate & + & + & + & + \\
\hline & $\begin{array}{l}\text { Dragendorff } \\
\text { reagent }\end{array}$ & $\begin{array}{l}\text { Brick red } \\
\text { precipitate }\end{array}$ & + & + & + & + \\
\hline Flavonoid & $\begin{array}{c}\text { Etanol }+\mathrm{Mg} \\
\text { powder }+\mathrm{HCl} 2 \mathrm{~N} \\
+\mathrm{HCl}(\mathrm{p})\end{array}$ & Red brick color & + & + & + & + \\
\hline Tannin & $\mathrm{NaCl}+$ Gelatin & $\begin{array}{l}\text { White sediment } \\
\text { formed }\end{array}$ & + & + & + & + \\
\hline Saponin & $\begin{array}{c}\text { Aquadest, then } \\
\text { shaken }+\mathrm{HCl}\end{array}$ & $\begin{array}{l}\text { Formed foam that } \\
\text { does not disappear }\end{array}$ & + & + & + & + \\
\hline $\begin{array}{c}\text { Steroid/ } \\
\text { Triterpenoid }\end{array}$ & $\begin{array}{c}\text { Kloroform + } \\
\text { Acidum Asetat } \\
\text { Anhidrat } \\
+\mathrm{H} 2 \mathrm{SO} 4(\mathrm{p})\end{array}$ & $\begin{array}{l}\text { A brownish green } \\
\text { ring is formed }\end{array}$ & + & + & + & + \\
\hline
\end{tabular}

Table 6: Total flavonoid content in Binahong leaf extract.

\begin{tabular}{cc}
\hline Weight of extract & Flavonoid Levels (\%) \\
\hline $50 \mathrm{mg}$ & 1,35 \\
\hline
\end{tabular}

Table 7: Results of the $96 \%$ ethanol extract containing Binahong leaves.

\begin{tabular}{|c|c|c|c|c|c|c|c|c|}
\hline No & $\begin{array}{c}\text { Component } \\
\text { name }\end{array}$ & $\begin{array}{c}\text { Identification } \\
\text { status }\end{array}$ & Observed m/z & $\begin{array}{c}\text { Neutral mass } \\
\text { (Da) }\end{array}$ & $\begin{array}{l}\text { Observed RT } \\
\text { (min) }\end{array}$ & Detector counts & Adducts & Formula \\
\hline 1 & Azedarachin C & Identified & 609.2715 & 586.27780 & 10.30 & 1413329 & $+\mathrm{Na}$ & $\mathrm{C} 32 \mathrm{H} 42 \mathrm{O} 10$ \\
\hline 2 & DO 21 & Identified & 577.1555 & 554.15768 & 5.27 & 3131290 & $+\mathrm{Na}$ & С32H26O9 \\
\hline 3 & Vitexin & Identified & 433.1119 & 432.10565 & 5.02 & 1863655 & $+\mathrm{H}$ & $\mathrm{C} 21 \mathrm{H} 20 \mathrm{O} 10$ \\
\hline 4 & $\begin{array}{c}\text { Candidate Mass } \\
593.27606\end{array}$ & Identified & 593.2761 & 592.26723 & 10.39 & 1557522 & $+\mathrm{H}$ & C34H40O9 \\
\hline 5 & $\begin{array}{c}\text { Candidate Mass } \\
797.51921\end{array}$ & Identified & 797.5192 & 796.51171 & 11.49 & 4974971 & $+\mathrm{H}$ & C31H72N8O15 \\
\hline
\end{tabular}

steroid compounds through the formation of conjugated double bonds and the presence of $\mathrm{H}_{2} \mathrm{O}$ release and incorporation of carbocation. Testing to identify polyphenol compounds is done by reacting with $1 \%$ $\mathrm{FeCl} 3$ solution. The results of tests that have been done show positive results. which shows the greenish-black color.

\section{Determination of total flavonoid levels}

Spectrophotometry analysis or quantitative analysis based on weight is the process of isolating and weighing an element or a particular compound from that element, in the purest form possible. From the results obtained total flavonoid vitexin in ethanol extract $96 \%$ of binahong leaves as much as $1.031 \%$.

\section{Identification of Vitexin content}

From the results obtained in the measurement of various variations in the ethanol concentration of compounds detected were Azedarachin C, DO 21, and vitexin. The results of observed $\mathrm{m} / \mathrm{z}$, neutral mass, observed Rt and detector count of each solvent could be seen in Table 6 .

The results of determining the active components of the ethanol extract of binahong leaves are presented in Table 7 . The alleged compounds in the binahong leaf extract are 5 compounds. Vitexin was detected in the analysis LC-MS / MS is one of the high-resolution analysis techniques and can be used in quantitative analysis and structural analysis so that it can provide a beneficial approach in determining the profile of a metabolite. Research conducted that $\mathrm{M} / \mathrm{Z}$ mine includes all the steps in the initial data processing LC-MS / MS chromatogram and is mainly used in metabolomic purposes, such as the identification of a compound in a sample. ${ }^{16} \mathrm{M} / \mathrm{Z}$ mine processes LC-MS / MS chromatograms into mass arrays. A mass array is a three-dimensional data matrix containing accurate mass information of the detected peak, retention time, and peak intensity. ${ }^{17}$ LC-MS / MS analysis with ionization techniques generally produces molecular ions $([\mathrm{M}+\mathrm{H}]+$ or $[\mathrm{M}+\mathrm{H}]-)$ depends on several factors such as the chemical properties of the analyte, the voltage polarity of the ESI, the nature of the matrix, and the composition of the solvent so that it is not natural to predict the ion charge generated in the treatment.

\section{CONCLUSION}

96\% ethanolic extract of binahong leaves contains vitexin with pharmacognostic parameters carried out following the standards listed in the Indonesian herb pharmacopeia.

\section{ACKNOWLEDGMENTS}

The authors would like to thank the Directorate Research and Community Service Universitas Indonesia Research Grant (TADok) 2019 certificate no. NKB-0090/UN2.R3.1/HKP.05.00/2019.

\section{REFERENCES}

1. Dipiro JT, Wells BG, Schwinghammer TL, Dipiro CV. Pharmacotherapy handbook. McGraw-Hill Education Companies, United States of America. 2015;161-2.

2. International Diabetes Federation. (2017). Eighth edition 2017. Retrieved from http://www.diabetesatlas.org/resources/2017-atlas.html

3. Katzung, BG, Trevor AJ. Basic \& Clinical Pharmacology Thirteenth Edition McGraw-Hill Education Companies. 2015;723-4. 
4. Abou Zeid AHS, Soliman FM, Sleem AA, Mitry MNR. Phytochemical and bioactivity investigations of the aerial parts of Anredera cordifolia (Ten.) Steenis. Bulletin of the National Research Centre. 2007;32(1):1-33.

5. Elya B, Handayani R, Saurisari R, Azizahwati Hasyyati US, Permana IT, et al. Antidiabetic activity and phytochemical screening of extracts from Indonesian plants by inhibition of alpha-amylase, alpha glucosidase, and dipeptidyl peptidase IV. Pakistan Journal of Biological Science. 2015;18(6):279-84.

6. Sukandar EY, Qowiyah A, Larasati L. Effect of methanol extract of heart leaf madeiravine (Anredera cordifolia(TEN.)STEENIS) leaves on blood sugar in diabetes mellitus model mice. Medika Planta Journal. 2011;1(4):1-10.

7. Basyuni M, Ginting PYA, Lesmana I. Phytochemical analysis of Binahong (Anredera Cordifolia) leaves extract to inhibit in Vitro growth of Aeromonas Hydrophila. AIP Conference Proceedings. 2017;1-5.

8. Djamil R, Winarti W, Zaidan S, Syamsudin A. Antidiabetic activity of flavonoid from binahong leaves (Anredera cordifolia) extract in alloxan induced mice. Journal of Pharmacognosy \& Natural Products. 2017;3(2):2-5.

9. Espada A, Rodriguez J, Villaverde MC, Riguera R. Hypoglycaemic triterpenoid saponins from Boussingaultia baselloides. Canadian Journal of Chemistry. 68(11):2039-44

10. Djamil R, Wahyudi PS, Wahono S, Hanafi M. Antioxidant activity of flavonoid from Anredera Cordifolia (TEN) steenis leaves. International Research Journal of Pharmacy. 2012;3(9):241-3.
11. Anonymous. Farmakope Herbal Indonesia. 1st ed. Department of Health of Republik of Indonesia. Jakarta, Indonesia, 2011.

12. Anonymous. Supplement II Farmakope Herbal Indonesia 1st ed. Directorate General of Drug and Food Supervision. Department of Health Republik of Indonesia. Jakarta, Indonesia. 2008;19-22

13. Bandiola. Extraction and qualitative phytochemical screening of medicinal plants: A brief summary. International Journal of Pharmacy. 2018;8(1):137-43.

14. Azwanida. A review on the extraction methods uses in medicinal plants, principle, strength, and limitation. Medicinal \& Aromatic Plants. 2015;4(3).

15. Tiwari P, Kumar B, Kaur M, Kaur G, Kaur H. Phytochemical screening and extraction: A Review. Dalam: International Pharmaceutica Sciencia. 2011;1(1).

16. Harborne J. A guide to modern techniques of plant analysis. Phytochemical methods. Chapman and Hall London. 1998.

17. Rahmawati L, Fachriyah EKD. Isolation, identification, and antioxidant activity test of flavonoids compound from binahong leaves. Chem Info. 2013:1(1):16573.

18. Selawa W, Runtuwene MRJ, Citraningtyas G. Flavonoid content and total antioxidant capacity of binahong leaf ethanol extract. Pharmacon Journal. 2013;2(01):18-23

19. Katajama M, Oresic M. Processing method for differential analiysis of LC/MS profile data. BioMed Center Bioinformatics. 2005;179.

\section{GRAPHICAL ABSTRACT}

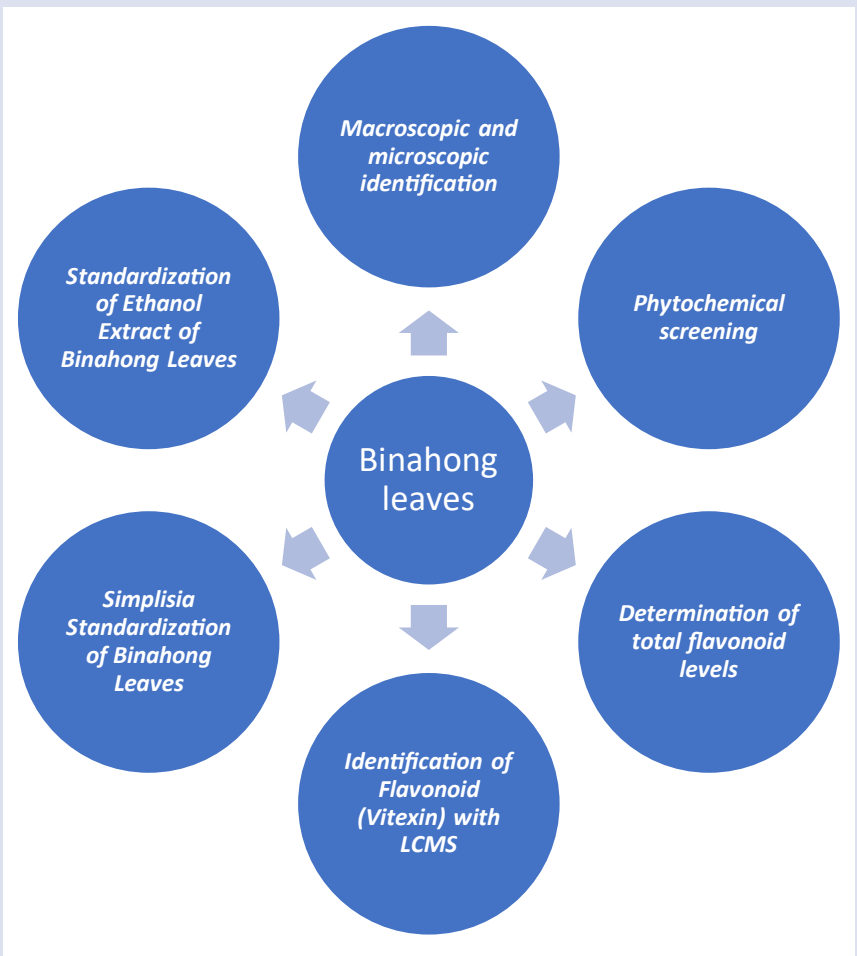

\section{SUMMARY}

- The microscopic binahong leaves contains palisade tissue, parenchymal tissue, chlorophyll grains, rosette Ca-oxalate crystals and spiral type.

- Phytochemical screening of binahong leaves showed the presence of alkaloids, flavonoids, saponins, tannins, steroids and phenolic compounds.

- LCMS profiles showed that ethanolic extract 40\%, 70\% and $96 \%$ all contained vitexin at retention time 5.02 minutes and $\mathrm{m} / \mathrm{z}$ values 433.1111.

- Ethanolic extract of binahong leaves with pharmacognosic parameters carried out in accordance with the standards listed in the Indonesian herb pharmacopoeia.

\section{ABOUT AUTHORS}

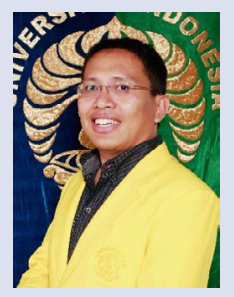

Dr. Anton Bahtiar, M.Biomed., Apt. Obtained his Ph.D. degree in 2010 from Nara Institute of Science and Technology, Japan. Currently, He is lecturer and researcher at faculty of pharmacy, University of Indonesia since 1998. He is also a head of Pharmacology and Toxicology Laboratory. His research projects are focus on Herbal medicine, and tried to solve the mechanism of action of herbal medicine, especially for osteoporosis and menopause. 


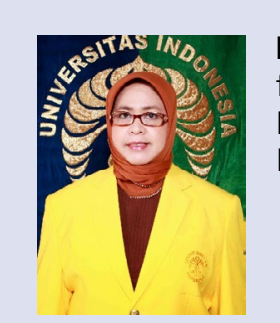

Prof. Dr. Yahdiana Harahap, M.Si.,Apt. got her undergraduate degree from Indonesian University in 1987 and finished her PhD from Bandung Institute of Technology in 2003. She is positioned as Professor at Pharmacy at Faculty of Pharmacy Indonesian Univesity. Her research is in Pharmaceutical Chemistry Analysis, especially Bioanalysis and DNA-Adduct Analysis.

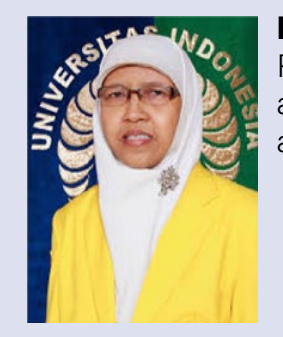

Prof. Dr. Berna Elya, M.Si., Apt. Professor and Head of Phytochemistry and Pharmacognosy, Faculty of Pharmacy, Universitas Indonesia (UI) Depok, West Java, Indonesia. She is expert in the area of Pharmacognosy and Phytochemistry, working in drug discovery of herbal plants, extraction technology, structure elucidation, and degenarative disease such as diabetes mellitus, antyhypertension, and cholesterol.

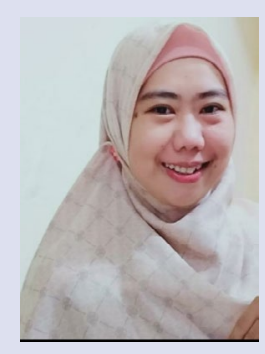

Dwitiyanti, M.Farm., Apt. a Doctoral Student at Department of Pharmaceutical Sciences, Faculty of Pharmacy, Universitas Indonesia, Depok, West Java, Indonesia, and also as a lecturer at Department of Pharmacy, Faculty of Pharmacy and Sciences, University of Muhammadiyah Prof. Dr. HAMKA, East Jakarta, Indonesia. The doctoral research focused on The Influence Of Binahong (Anredera Cordifolia (Ten.) Steenis) Extract On Pharmacodynamics And Pharmacokinetic Glybenclamide.

Cite this article: Dwitiyanti, Harahap Y, Elya B, Bahtiar A. Impact of Solvent on the Characteristics of Standardized Binahong Leaf (Anredera cordifolia (Ten.) Steenis). Pharmacog J. 2019;11(6)Suppl:1463-70. 